\title{
The Study on Biological and Pharmacological Activity of Coumarins
}

\author{
Ling Xu \\ College of Pharmaceutical Science \\ Zhejiang University of Technology \\ Hangzhou, China \\ e-mail:1025637878@qq.com
}

Xiao-Yin Zhao

College of Pharmaceutical Science

Zhejiang University of Technology

Hangzhou, China

e-mail: zhaoxiaoyin@zjut.edu.cn

\author{
Yan-Ling $\mathrm{Wu}^{*}$ \\ Lab of Molecular Immunology \\ Zhejiang Provincial Center for Disease Control and \\ Prevention \\ Hangzhou, China \\ e-mail: ylwu@cdc.zj.cn \\ Wen Zhang ${ }^{*}$ \\ College of Pharmaceutical Science \\ Zhejiang University of Technology \\ Hangzhou, China \\ e-mail: wzhang63@zjut.edu.cn
}

\begin{abstract}
Coumarin has drawn much attention due to its wide range of pharmacological effects such as anti-tumor, anti-coagulant, anti-inflammatory, anti-oxidant, anti-HIV and anti-bacterial. In clinic, coumarin derivatives have been used as anticoagulant and rheumatoid arthritis therapy. Coumarins have become the research hot point based on their different treatment effects to diseases and less damage to normal cells. This review highlights the anti-inflammatory, anti-coagulant, anti-cancer activity and Alzheimer's disease (AD) inhibition of the natural and synthetic coumarins, specifically elaborates the different mechanisms of anticancer effects of the coumarin derivatives, providing a support for further cancer treatment.
\end{abstract}

Keywords-Coumarin; classification; biological activity; pharmacological activity.

\section{INTRODUCTION}

Coumarin (Fig. 1) is a large class of natural extract products, it considered to be the secondary metabolites in many higher plants species, particularly in leaves, seeds and roots, especially exists in the Rutaceae and Umbrelliferae plants. It was been found in the tonka bean and the name of coumarin comes from a French word coumarou. Coumarin plays an important role in regulation of plants growth and metabolites [1]. According to the different substituents in the overring, the coumarins can classified into simple coumarins, furano coumarins, pyrano coumarins and other coumarins, of which the furano coumarins and pyrano coumarins can divided into linear type and angular type. Both natural and synthetic coumarin derivatives are considered to have a wide range of biological activity, such as anti-inflammatory [2], anticancer [3, 4], anti-coagulant, anti-oxidant, as well as antiHIV and anti-bacterial [5]. Biological activity of coumarins has becoming an appealing point of studies owing to its different effects to diseases and less damage to normal cells [6]. Previous studies demonstrated that coumarin chalcone fibrates can down-regulate the total cholesterol (TC), phospholipids (PL), and triglycerides (TG), and regulate the levels of VLDL, LDL and HDL [7].
Furthermore, 4-hydroxycoumarin dimers and benzopyranocoumarin derivatives showed a powerful effect against HSV-1, HSV-2 and vaccinia virus at a nontoxic concentration [8].<smiles>COc1ccccc1C</smiles>

Figure 1. The mother structure of coumarin.

\section{ClassificAtion OF COUMARINS}

Coumarins are made of fused benzene and $\alpha$-pyrone rings, on the basis of different substituents on coumarin nucleus, coumarins can classified into four types (Table 1). Ammoresinol, Ostruthin, Novobiocin, Coumermysin and Chartreusin belong to simple coumarins with antibacterial activity and Osthole has the biological activity of anti-cancer[9]. Furano coumarin consists of Imperatorin, Psoralen, Bergapten Marmalde and other compounds with anti-inflammatory, anti-TB and antifungal activities. There are two types of pyrano coumarins, linear type including Grandivittin, Agasyllin and Aegelinol benzoate [10] with the anti-bacterial activity and angular type including Inophyllum (A, B, C, E, P, G), Calanolide (A, B, $\mathrm{F})[11]$, and Pseudocordatolide[9] having the antiviral activity. In addition to the types above mentioned, the structure of natural coumarins also have other typies, such as bicoumarins, which have the pharmacological activity of anticoagulant. Some coumarins having biological activity are summarized in Fig. 2.

\section{BIOLOGICAL AND PHARMACOLOGICAL ACTIVITY OF COUMARINS}

\section{A. Anti-inflammatory Activity}

Inflammation is a significant denotation of many diseases, such as osteoarthritis, Alzheimer's disease, atherosclerosis and other diseases [12]. Also many 
cancers are associated with chronic inflammation. Therefore, get command of inflammatory becomes more important in many diseases treatment. A coumarin derivative IMMLG5521 (Fig. 2A) has the anti- inflammatory activity of rat lung edema, which exhibits its effects by inhibiting the TNF- $\alpha$ expression, increasing the VCAM-1 and ICAM-1 expression level [13].

TABLE I. THE TYPES OF COUMARINS AND THEIR PHARMACOLIGICAL ACTIVITIES.

\begin{tabular}{|c|c|c|c|}
\hline $\begin{array}{l}\text { Type of } \\
\text { coumarin }\end{array}$ & General chemical structure & $\begin{array}{l}\text { Example } \\
\text { with reference }\end{array}$ & $\begin{array}{l}\text { Pharmacological } \\
\text { activity }\end{array}$ \\
\hline $\begin{array}{l}\text { Simple } \\
\text { coumarins }\end{array}$ & & $\begin{array}{l}\text { Coumarin Ammoresinol, } \\
\text { Ostruthin Novobiocin, } \\
\text { Coumermysin } \\
\text { Chartreusin }\end{array}$ & $\begin{array}{l}\text { Anti-inflammatory, } \\
\text { Anti-bacterial, } \\
\text { Antifungal, } \\
\text { Anti-cancer }\end{array}$ \\
\hline $\begin{array}{l}\text { Furano } \\
\text { coumarins }\end{array}$ & & $\begin{array}{l}\text { Imperatorin, } \\
\text { Psoralen, } \\
\text { Bergapten Marmalde }\end{array}$ & $\begin{array}{l}\text { Anti-inflammatory, } \\
\text { Anti-TB, } \\
\text { Antifungal }\end{array}$ \\
\hline \multirow[t]{2}{*}{$\begin{array}{l}\text { Pyrano } \\
\text { coumarins }\end{array}$} & & $\begin{array}{l}\text { Grandivittin, } \\
\text { Agasyllin Xanthyletin }\end{array}$ & $\begin{array}{l}\text { Anti-bacterial, } \\
\text { Anti-TB }\end{array}$ \\
\hline & & $\begin{array}{l}\text { Inophyllum (A, B, C, E, } \\
\text { P, G), } \\
\text { Calanolide }(A, B, F)\end{array}$ & Antiviral \\
\hline $\begin{array}{l}\text { Other } \\
\text { coumarins }\end{array}$ & & Dicoumarol & Anticoagulant \\
\hline
\end{tabular}

A

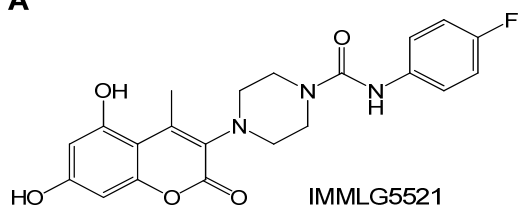

C $\mathrm{OOCH}_{3}$<smiles>CCOC(=O)Cc1c(C)c2ccc(OC)c(C)c2oc1=O</smiles><smiles>CC1COCCN1/N=C/c1c(Cl)c2cc(Br)ccc2oc1=O</smiles>

RKS262<smiles>Cc1cn(C2CC(n3cc(COc4cc(=O)oc5ccccc45)nn3)C(CO)O2)c(=O)[nH]c1=O</smiles>

I<smiles>CCOCCOCCOc1cc2ccc(CC#N)cc2oc1=O</smiles><smiles>[B]Oc1ccc2c(C)c(CC(=O)OCC)c(=O)oc2c1O</smiles>

DHEMC

D<smiles>CC(=O)CC(c1ccccc1)c1c(OC(C)=O)c2ccccc2oc1=O</smiles><smiles></smiles>

SV25

H<smiles>Cn1c(Cn2cc(COc3cc(=O)oc4ccccc34)nn2)cc2ccccc21</smiles>

Figure 2: Some coumarin derivatives with the different biological activities. 
4-Methylcoumarin Derivatives DHEMC and DAEMC (Fig. 2B and 2C) showed the anti-inflammatory effects on Activated Microglial Cells, these two compounds can decrease the inflammatory enzymes, inducing nitric oxide synthase (iNOS) and cyclooxygenase-2 (COX-2), and effectively inhibit the inflammatory pathway to regulate the inflammation in rat microglial cells[14]. Two series of designed coumarin-benzimidazole derivatives by Yogita Bansal's group showed significant anti-inflammatory (the best compound inhibit $46.75 \%$ inflammatory reaction on rats) and antioxidant (the best compound's $\mathrm{IC}_{50}$ is $1.2 \mu \mathrm{M}$ ) activities and did not damage the gastric mucosa and not cause to oxidative stress in tissues [15].

\section{B. Anticoagulant activity}

Vitamin $\mathrm{K}$ plays an important role in blood coagulation. As shown In Fig. 2D, the structure of warfarin is similar to vitamin $\mathrm{K}$ and it has anticoagulant activity as the Vitamin $\mathrm{K}$ antagonist. The initial use of Warfarin acts as the poison to exterminate rats and then it has been the drug of anticoagulant for almost 60 years. Warfarin exerts its anticoagulant activity by inhibiting the formation of Vitamin $\mathrm{K}$ dependent coagulation factors (II, VII, IX, X) in the liver microsomal. Vitamin $\mathrm{K}$ can prompt the Vitamin $\mathrm{K}$ dependent coagulation factors (II, VII, IX, X) N-terminal glutamate residues to form $\gamma$ carboxyglutamates [16]. The reduced vitamin $\mathrm{K}\left(\mathrm{Vit} \mathrm{KH}_{2}\right)$ participates in the $\gamma$-carboxylation, and Warfarin inhibits the epoxide reductase to block the $\mathrm{Vit} \mathrm{KH}_{2}$ formation (Fig. $3)$.

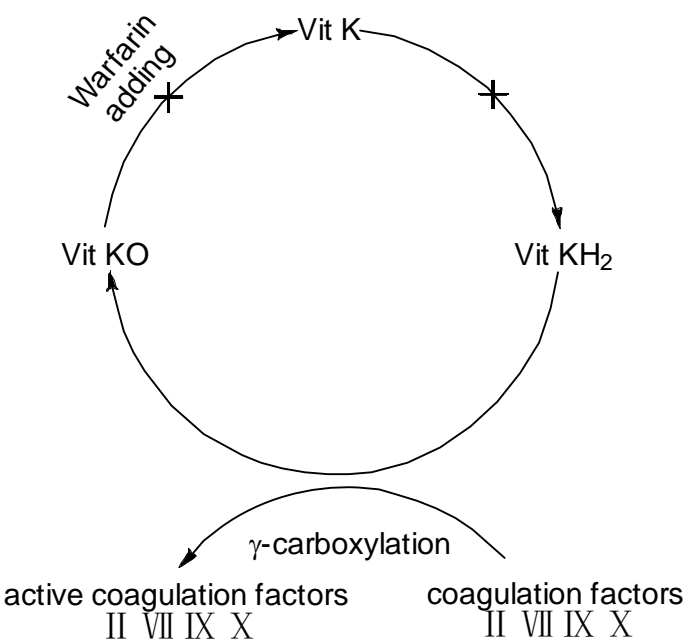

Figure 3: The action mechanism of Warfarin anticoagulant.

\section{Anticancer activity}

Malignancies have become the biggest threat to human health. The anticancer activity seems to be the most important properties of coumarins, although all different interaction mechanisms are not far from clear. A coumarin derivative (RKS262) (Fig. 2E) synthesized could inhibit ovarian cancer cells proliferation. This compound exhibited its anticancer activity by reducing the mitochondria-transmembrane-depolarization potential, regulating the mitochondrial $\mathrm{Bcl}-2$ family pathway, increasing the pro-apoptotic factors Bid, Bad and Box expression, and decreasing the expression of Bcl-xl and
Mcl-1 [17]. A new synthesized dicoumarin polysulfides SV25 (Fig. 2F) has supported this mechanism, which arrested HCT116 colorectal cancer cell in $\mathrm{G}_{2} / \mathrm{M}$ phase of the cell cycle and up-regulated the bax and cytochrome $c$ level and cleavage of caspase 3 and caspase 7[18]. Recent study shows coumarin derivatives $\operatorname{Tr} 1$ and Tr2 (Fig. 2G and $2 \mathrm{H}$ ) can interact with the G-quadruplex and stabilize it [19]. This exciting discovery showed a new target of cancer treatment. Furthermore, another coumarin, 7Diethyl amino-3(2 0-benzoxazolyl)-coumarin (DBC), exerts its anticancer effects by inhibiting the microtubule and arresting the tumor cells at $\mathrm{G}_{2} / \mathrm{M}$ stage, and its damage to human normal fibroblast is less than to the tumor cells [20]. Colorectal carcinoma is the most common cancer in Western Europe and North America countries. 5,7-dihydroxy-4-methyl-6-(3-methylbutanoyl)coumarin (DMAC, Fig. 2J) designed by Cheng-Wei Lin group can inhibit the colon cancer cell HCT116 and LoVo cells, the results demonstrating that the compound DMAC induce cell apoptosis by increasing the expression of proapoptotic protein Bak and activating the cleaved caspase-3 and PARP; in addition, the DMAC induced celluar shrinkage, chromatin condensation and annxin $\mathrm{V}$ detection [21].

\section{Alzheimer's disease Inhibition}

Alzheimer's disease (AD) is the degenerative disease of the central nervous system characterized by memory impairment, cognitive dysfunction, personality change and language barrier [22]. In elderly people, AD is the most common disease and the number of people who suffer from $A D$ is sharply increased. However, the etiology of $\mathrm{AD}$ is far from understood, many researches show that low levels of acetylcholine (ACh), amyloid- $\beta$ $(\mathrm{A} \beta)$ formations and oxidative stress appeared in patients [23-25]. Recent researches showed that coumarin derivatives can inhibit the AD. Maria Joao Matos group designed and synthesized a series of 3-substituted coumarin derivatives, for which the results of biology evaluation demonstrate that these compounds can both inhibit the MAO-A (Monoamine oxidase A) and MAO-B (Monoamine oxidase $\mathrm{B}$ ) isoforms and $\mathrm{AChE}$ (acetylcholinesterase) in the micromolar range . A series of tacrine-coumarin hybrids designed and synthesized by Xiao-Bing Wang group showed a significant ability against $\mathrm{AD}$ by inhibiting the cholinesterase $(\mathrm{ChE})$ and inducing $\beta$-amyloid $(A \beta)$ aggregation, a compound of which exhibits the best activity $\mathrm{IC}_{50}=0.092 \mu \mathrm{M}$ for inhibiting $\mathrm{AChE}$, also showing a great ability to inhibiting butyrylcholinesterase $(\mathrm{BuChE})$ whth $\mathrm{IC}_{50}=0.234 \mu \mathrm{M}$; furthermore, the compound displays its activity by binding and activating the AChE peripheral and midgorge sites [27].

\section{CONCLUSIONS}

Coumarin derivatives have received increasing attention for their wide biological and pharmacological activities. We summarized the anti-inflammatory, anticoagulant and anti-cancer activity etc. for natural and synthesized coumarins. The anticancer effect of the coumarins is the most important one in these biological activities and the G-quadruplex interacting with coumarins may be a new target of the protooncogene for 
further cancer treatment. The review is of importance for the design and development of the coumarin derivatives as novel lead molecules for disease therapy.

\section{ACKNOWLEDGMENT}

This work was financially supported by Zhejiang Provincial Natural Science Foundation of China (LY12B02019) and the Program for Zhejiang Leading Team of Science and Technology Innovation (2011R50021).

\section{REFERENCES}

[1] M.A. Musa, J.S. Cooperwood and M.O.F. Khan, "A review of coumarin derivatives in pharmacotherapy of breast cancer", Current medicinal chemistry, vol. 15, 2008, pp. 2664-2679, doi:10.2174/092986708786242877.

[2] A. Witaicenis, L.N. Seito, A. da Silveira Chagas, L.D. de Almeida Junior, A.C. Luchini, P. Rodrigues-Orsi, et al., "Antioxidant and intestinal anti-inflammatory effects of plant-derived coumarin derivatives", Phytomedicine, vol. 21, 2014, pp. 240-246, doi:10.1016/j.phymed.2013.09.001.

[3] T. Nasr, S. Bondock and M. Youns, "Anticancer activity of new coumarin substituted hydrazide-hydrazone derivatives", European journal of medicinal chemistry, vol. 76, 2014, pp. 539-548, doi:10.1016/j.ejmech.2014.02.026.

[4] J. Bronikowska, E. Szliszka, D. Jaworska, Z.P. Czuba and W. Krol "The coumarin psoralidin enhances anticancer effect of tumor necrosis factor-related apoptosis-inducing ligand (TRAIL)", Molecules, vol. 17, 2012, pp. 6449-6464, doi:10.3390/molecules 17066449 .

[5] C. Canning, S. Sun, X. Ji, S. Gupta and K. Zhou, "Antibacterial and cytotoxic activity of isoprenylated coumarin mammea A/AA isolated from Mammea africana ", Journal of ethnopharmacology, vol. 147, 2013, pp. 259-262, doi:10.1016/j.jep.2013.02.026.

[6] H. Murat Bilgin, M. Atmaca, B. Deniz Obay, S. Özekinci, E. Taşdemir and A. Ketani, "Protective effects of coumarin and coumarin derivatives against carbon tetrachloride-induced acute hepatotoxicity in rats", Experimental and Toxicologic Pathology, vol. 63, 2011, pp. 325-330, doi:10.1016/j.etp.2010.02.006.

[7] K.V. Sashidhara, G.R. Palnati, R. Sonkar, S.R. Avula, C. Awasthi and G. Bhatia, "Coumarin chalcone fibrates: A new structural class of lipid lowering agents", European journal of medicinal chemistry, vol. 64, 2013, pp. 422-431, doi:10.1016/j.ejmech.2013.04.026.

[8] D. Završnik, S. Muratović, D. Makuc, J. Plavec, M. Cetina, A. Nagl, et al., "Benzylidene-bis-(4-hydroxycoumarin) and benzopyrano-coumarin derivatives: synthesis, 1H/13C-NMR conformational and $\mathrm{X}$-ray crystal structure studies and in vitro antiviral activity evaluations", Molecules, vol. 16, 2011, pp. 60236040, doi:10.3390/molecules16076023.

[9] K.N. Venugopala, V. Rashmi and B. Odhav, "Review on natural coumarin lead compounds for their pharmacological activity", Biomed Res Int, vol. 2013, 2013, pp. 963248, doi: $10.1155 / 2013 / 963248$.

[10] A. Basile, S. Sorbo, V. Spadaro, M. Bruno, A. Maggio, N. Faraone, et al., "Antimicrobial and antioxidant activities of coumarins from the roots of Ferulago campestris (Apiaceae)", Molecules, vol. 14, 2009, pp. 939-952, doi:10.3390/molecules14030939.

[11] K. Mishra, "Plant derived antivirals: a potential source of drug development", Journal of Virology \& Antiviral Research, vol. 2013, pp. doi:10.4172/2324-8955.1000109.

[12] R. Medzhitov, "Inflammation 2010: new adventures of an old flame", Cell, vol. 140, 2010, pp. 771-776, doi:10.1016/j.cell.2010.03.006.

[13] Z. Li, J. Hu, M. Sun, H. Ji, S. Chu, G. Liu, et al., "Antiinflammatory effect of IMMLG5521, a coumarin derivative, on Sephadex-induced lung inflammation in rats", International immunopharmacology, vol. 14, 2012, pp. 145-149, doi:10.1016/j.intimp.2012.06.004.
[14] A.R. Togna, O. Firuzi, V. Latina, V.S. Parmar, A.K. Prasad, A Salemme, et al., "4-Methylcoumarin Derivatives with Antiinflammatory Effects in Activated Microglial Cells", Biological and Pharmaceutical Bulletin, vol. 37, 2014, pp. 60-66, doi:10.1248/bpb.b13-00568.

[15] R.K. Arora, N. Kaur, Y. Bansal and G. Bansal, "Novel coumarinbenzimidazole derivatives as antioxidants and safer antiinflammatory agents", Acta Pharmaceutica Sinica B, vol. 2014, pp. doi:10.1016/j.apsb.2014.07.001.

[16] J. Hirsh, J.E. Dalen, D.R. Anderson, L. Poller, H. Bussey, J. Ansell, et al., "Oral anticoagulants: mechanism of action, clinical effectiveness, and optimal therapeutic range", Chest Journal, vol. 119, 2001, pp. 8S-21S, doi:10.1378/chest.119.1_suppl.8S.

[17] R.K. Singh, T.S. Lange, K.K. Kim and L. Brard, "A coumarin derivative (RKS262) inhibits cell-cycle progression, causes proapoptotic signaling and cytotoxicity in ovarian cancer cells", Investigational New Drugs, vol. 29, 2011, pp. 63-72, doi:10.1007/s10637-009-9335-4.

[18] N.E. Saidu, S. Valente, E. Bana, G. Kirsch, D. Bagrel and M. Montenarh, "Coumarin polysulfides inhibit cell growth and induce apoptosis in HCT116 colon cancer cells", Bioorganic \& Medicinal Chemistry, vol. 20, 2012, pp. 1584-1593, doi:10.1016/j.bmc.2011.12.032.

[19] G. Raju, R. Srinivas, M.D. Reddy, C.R. Reddy and N. Nagesh, "Studies on Non-Covalent Interaction of Coumarin Attached Pyrimidine and 1-Methyl Indole 1, 2, 3 Triazole Analogues with Intermolecular Telomeric G-Quadruplex DNA Using ESI-MS and Spectroscopy", Nucleosides, Nucleotides and Nucleic Acids, vol. 33, 2014, pp. 489-506, doi:10.1080/15257770.2014.891742.

[20] S.N. Kim, N.H. Kim, Y.S. Park, H. Kim, S. Lee, Q. Wang, et al., "7-Diethylamino-3(2'-benzoxazolyl)-coumarin is a novel microtubule inhibitor with antimitotic activity in multidrug resistant cancer cells", Biochemical Pharmacology, vol. 77, 2009, pp. 1773-1779, doi:10.1016/j.bcp.2009.03.007.

[21] M.H. Lin, C.H. Cheng, K.C. Chen, W.T. Lee, Y.F. Wang, C.Q. Xiao, et al., "Induction of ROS-independent JNK-activationmediated apoptosis by a novel coumarin-derivative, DMAC, in human colon cancer cells", Chemico-Biological Interactions, vol. 218, 2014, pp. 42-49, doi:10.1016/j.cbi.2014.04.015.

[22] P. Anand, B. Singh and N. Singh, "A review on coumarins as acetylcholinesterase inhibitors for Alzheimer's disease", Bioorganic \& Medicinal Chemistry, vol. 20, 2012, pp. 1175-1180, doi:10.1016/j.bmc.2011.12.042.

[23] G.M. McKhann, D.S. Knopman, H. Chertkow, B.T. Hyman, C.R. Jack Jr, C.H. Kawas, et al., "The diagnosis of dementia due to Alzheimer's disease: Recommendations from the National Institute on Aging-Alzheimer's Association workgroups on diagnostic guidelines for Alzheimer's disease", Alzheimer's \& Dementia, vol. 7, 2011, pp. 263-269, doi:10.1016/j.jalz.2011.03.005.

[24] R.A. Sperling, P.S. Aisen, L.A. Beckett, D.A. Bennett, S. Craft, A.M. Fagan, et al., "Toward defining the preclinical stages of Alzheimer's disease: Recommendations from the National Institute on Aging-Alzheimer's Association workgroups on diagnostic guidelines for Alzheimer's disease", Alzheimer's \& Dementia, vol. 7, 2011, pp. 280-292, doi:10.1016/j.jalz.2011.03.003.

[25] M. Huang, S.-S. Xie, N. Jiang, J.-S. Lan, L.-Y. Kong and X.-B. Wang, "Multifunctional Coumarin Derivatives: Monoamine Oxidase $\mathrm{B}$ (MAO-B) Inhibition, Anti- $\beta$-Amyloid (A $\beta)$ Aggregation and Metal Chelation Properties against Alzheimer's Disease", Bioorganic \& medicinal chemistry letters, vol. 2014, pp. doi:10.1016/j.bmcl.2014.12.034.

[26] D. Viña, M.J. Matos, M. Yáñez, L. Santana and E. Uriarte, "3Substituted coumarins as dual inhibitors of AChE and MAO for the treatment of Alzheimer's disease", Medicinal Chemistry Communications, vol. 3, 2012, pp. 213-218, doi:10.1039/c1md00221j.

[27] S.-S. Xie, X.-B. Wang, J.-Y. Li, L. Yang and L.-Y. Kong, "Design, synthesis and evaluation of novel tacrine-coumarin hybrids as multifunctional cholinesterase inhibitors against Alzheimer's disease", European journal of medicinal chemistry, vol. 64, 2013, pp. 540-553, doi:10.1016/j.ejmech.2013.03.051. 